\title{
Human herpesvirus 6 in cerebrospinal fluid of patients infected with HIV: frequency and clinical significance
}

\author{
Simona Bossolasco, Roberta Marenzi, Helena Dahl, Luca Vago, Maria Rosa Terreni, \\ Francesco Broccolo, Adriano Lazzarin, Annika Linde, Paola Cinque
}

\begin{abstract}
The objective was to evaluate the frequency of human herpesvirus 6 (HHV-6) DNA detection in the CSF of patients infected with HIV and its relation to brain disease and systemic HHV-6 infection.

Nested polymerase chain reaction (PCR) was used to analyse CSF samples from 365 consecutive HIV infected patients with neurological symptoms. When available, plasma and brain tissues from patients whose CSF was HHV-6 positive were also studied.

HHV-6 was found in the CSF of eight of the 365 patients $(2.2 \%)$ : two had type $A$ and four type B; the HHV-6 variant could not be defined in the remaining two. All eight patients had neurological symptoms and signs related to concomitant opportunistic brain diseases, including cytomegalovirus (CMV) encephalitis in five patients whose CSF was also positive for CMV-DNA. Opportunistic infections but no other unexplained lesions were also found in the brain of all of the four patients who underwent neuropathological examination. Both HHV-6 and CMV were also detected in the plasma of respectively five and seven of seven patients whose CSF was HHV-6 positive.

In conclusion, HHV- 6 type $A$ or $B$ DNA was infrequently found in the CSF of HIV infected patients, in association with both CMV brain infection and systemic HHV-6 replication. However, no certain relation between HHV-6 and brain disease was found.

(F Neurol Neurosurg Psychiatry 1999;67:789-792)
\end{abstract}

Keywords: HIV infection; human herpesvirus type 6; cerebrospinal fluid; cytomegalovirus

Human herpesvirus 6 (HHV-6), variants A and $\mathrm{B}$, is a ubiquitous lymphotropic virus. HHV-6 B is known to be the causative agent of exanthema subitum, but both variants have been found in immunocompromised patients. ${ }^{1}$

Clinical evidence supports a role for HHV-6 in causing significant CNS disease. The virus is often found in the CSF of children with febrile convulsions or other neurological symptoms complicating exanthema subitum. ${ }^{2-4}$ HHV-6 encephalitis or milder neurological symptoms have been described in both immunocompetent adults and transplanted patients, ${ }^{5-7}$ and the virus might also play an aetiological part in multiple sclerosis. ${ }^{8} \mathrm{HHV}-6$ has also been found in the brain or CSF of adults and children with AIDS, but its role in neurological disease is still unclear. ${ }^{9-12}$

To study the possible relation between HHV- 6 and brain disease in patients infected with HIV, the presence of HHV-6-DNA in the CSF was assessed in a large group of patients with neurological disease and was correlated with clinical and neuropathology patterns.

\section{Patients and methods}

The CSF of 365 consecutive patients infected with HIV admitted to San Raffaele Hospital in the period 1992-6, was prospectively examined for the presence of HHV-6-DNA by polymerase chain reaction (PCR). All patients included in the study had CNS symptoms or signs at a physical examination and no contraindications for undergoing a lumbar puncture. Clinical neurological, neuroradiological, and CSF examination, also including DNA-PCR for the identification of herpes simplex virus type 1 and 2 (HSV-1, HSV-2), Varicella zoster virus (VZV), cytomegalovirus (CMV), Epstein-Barr virus (EBV), and JC virus $(\mathrm{JCV})^{11}$ were done at the onset of clinical manifestations. The CSF findings relating to 286 of these patients have been presented previously. ${ }^{11}$ In patients whose CSF was positive for HHV-6-DNA, all of the available CSF and plasma samples drawn at or after the onset of neurological manifestations, and kept stored at $-80^{\circ} \mathrm{C}$, were retrospectively examined. HHV-6 PCR was also applied to CSF and plasma samples taken from 20 neurologically asymptomatic HIV seronegative controls (patients who had undergone spinal anaesthesia) and to plasma samples drawn from $22 \mathrm{HIV}$ infected patients with other CNS diseases whose CSF was HHV-6-DNA negative. In all patients the CSF samples were drawn for diagnostic purposes and all of the patients and controls gave their informed con- 


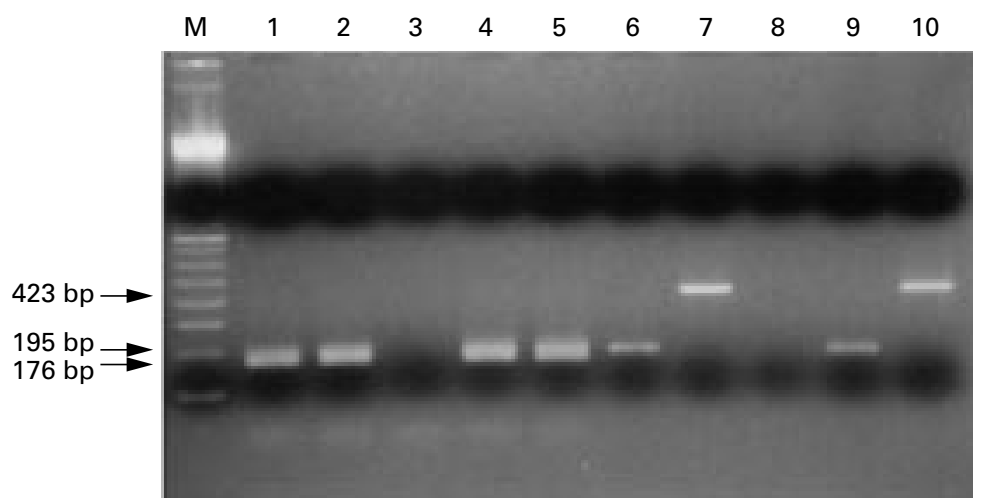

Agarose gel electrophoresis of amplification products after nested PCR for HHV-6 DNA using the standard assay, which amplifies a 173 bp DNA fragment (lanes 1-5) or the subtype PCR assay, which amplifies a 195 bp DNA fragment for group $A$ and a $423 \mathrm{bp} D N A$ fragment for group $B$ (lanes $6-10) . M=100 \mathrm{bp} D N A$ ladder marker; lanes $1,6=H H V-6$ variant $A$ positive CSF (patient 1 of the table); lanes $2,7=H H V-6$ variant $B$ positive CSF (patient 2 of the table); lanes 3, $8=D N A$-free control; lanes 4, $9=H H V-6$ variant $A$ positive control ( $G S$ strain); lanes $5,10=H H V-6$ variant $B$ positive control (Z29 strain).

sent for the CSF sampling in an approved manner.

A nested PCR for HHV-6-DNA detection was carried out as previously described. ${ }^{6}$ The positive samples were also tested by another PCR assay which gives products of different sizes for the HHV-6 A and B variants, allowing their differentiation ("subtype" PCR, figure). ${ }^{13}$ The analytical sensitivity was estimated to be 20 and 50 HHV-6 genomes for the standard and the subtype PCR, respectively. ${ }^{6}$ Pre-PCR treatment of CSF and plasma specimens and visualisation of amplified products was done as described. ${ }^{11}$ PCR examinations were done blindly with respect to the patients' history in the 365 prospectively examined patients.

Postmortem CNS examinations were performed in three patients (time interval between the CSF sampling and necropsy was 1-90 days), and brain biopsy in one. The postmortem examinations involved eight standard tissue sections and sections from any other macroscopically visible lesion. ${ }^{11}$ Tissues were fixed in formalin, embedded in paraffin, and examined after haematoxylin and eosin staining. Special stainings and immunochemical techniques were used for the diagnosis of opportunistic diseases and HIV encephalitis, as

PCR, clinical, and histopathological findings in HIV infected patients whose CSF was positive for HHV-6 DNA

\begin{tabular}{|c|c|c|c|c|c|c|c|c|c|}
\hline \multirow[b]{2}{*}{ Patient } & \multirow[b]{2}{*}{ Sample } & \multirow[b]{2}{*}{$(\text { days })^{*}$} & \multicolumn{7}{|c|}{ DNA PCR findings } \\
\hline & & & $\begin{array}{l}\text { CSF HHV-6 } \\
\text { (variant) }\end{array}$ & $\begin{array}{l}C S F \\
C M V\end{array}$ & $\begin{array}{l}\text { Plasma } H H V-6 \\
\text { (variant) }\end{array}$ & $\begin{array}{l}\text { Plasma } \\
\text { CMV }\end{array}$ & $\begin{array}{l}\text { Antiherpes treatment } \\
\text { (days) }\end{array}$ & CNS disease (diagnostic procedure) & $\begin{array}{l}\text { CNS HHV-6 } \\
\text { DNA PCR }\end{array}$ \\
\hline 1 & $\begin{array}{l}\mathrm{a} \\
\mathrm{b} \\
\mathrm{c} \\
\mathrm{d} \\
\mathrm{e}\end{array}$ & $\begin{array}{l}(-210) \\
0 \\
(+5) \\
(+14) \\
(+30)\end{array}$ & $\begin{array}{l}\text { NA } \\
+(\mathrm{A}) \\
+(\mathrm{A}) \\
+(\mathrm{A}) \\
+(\mathrm{A})\end{array}$ & $\begin{array}{l}\text { NA } \\
+ \\
+ \\
+ \\
+\end{array}$ & $\begin{array}{l}+(\mathrm{A}) \\
\mathrm{NA} \\
+(\mathrm{A}) \\
\mathrm{NA} \\
-\end{array}$ & $\begin{array}{l}+ \\
\text { NA } \\
+ \\
\text { NA } \\
+\end{array}$ & $\begin{array}{l}\text { Ganciclovir } \\
\text { (from-170 to }+30 \text { ) }\end{array}$ & $\begin{array}{l}\text { CMV meningoencephalomyeloradiculitis } \\
\text { HIV encephalopathy } \\
\text { (clinical+necropsy) }\end{array}$ & - \\
\hline 2 & $\begin{array}{l}\mathrm{a} \\
\mathrm{b} \\
\mathrm{c} \\
\mathrm{d}\end{array}$ & $\begin{array}{l}0 \\
(+12) \\
(+28) \\
(+55)\end{array}$ & $\begin{array}{l}+(\mathrm{ND}) \\
+(\mathrm{ND}) \\
+(\mathrm{B}) \\
+(\mathrm{B})\end{array}$ & $\begin{array}{l}+ \\
- \\
+ \\
-\end{array}$ & $\begin{array}{l}+(\mathrm{B}) \\
+(\mathrm{B}) \\
- \\
-\end{array}$ & $\begin{array}{l}+ \\
+ \\
+ \\
+\end{array}$ & $\begin{array}{l}\text { Ganciclovir } \\
\text { (from+40 to }+55)\end{array}$ & $\begin{array}{l}\text { Toxoplasmosis, CMV encephalitis } \neq \\
\text { (clinical+necropsy) }\end{array}$ & $+(\mathrm{ND}) \Omega$ \\
\hline 3 & $\begin{array}{l}\mathrm{a} \\
\mathrm{b} \\
\mathrm{c}\end{array}$ & $\begin{array}{l}0 \\
(+182) \\
(+421)\end{array}$ & $\begin{array}{l}+(\mathrm{B}) \\
+(\mathrm{B}) \\
+(\mathrm{B})\end{array}$ & $\begin{array}{l}- \\
- \\
-\end{array}$ & $\begin{array}{l}- \\
\text { NA } \\
+(B)\end{array}$ & $\begin{array}{l}- \\
\text { NA } \\
+\end{array}$ & None & $\begin{array}{l}\text { Toxoplasmosis } \\
\text { (clinical) }\end{array}$ & NA \\
\hline 4 & $\begin{array}{l}\text { a† } \\
\mathrm{b} \\
\mathrm{c}\end{array}$ & $\begin{array}{l}0 \\
(+5) \\
(+24)\end{array}$ & $\begin{array}{l}+(B) \\
\text { NA } \\
+(B)\end{array}$ & $\begin{array}{l}+ \\
+\end{array}$ & $\begin{array}{l}+(\mathrm{B}) \\
+(\mathrm{B}) \\
\mathrm{NA}\end{array}$ & $\begin{array}{l}+ \\
+ \\
-\end{array}$ & $\begin{array}{l}\text { Ganciclovir } \\
\text { (from-2 to+18) }\end{array}$ & $\begin{array}{l}\text { CMV meningoencephalitis } \\
\text { (clinical) }\end{array}$ & NA \\
\hline 5 & a & 0 & $+(\mathrm{A})$ & - & $+(\mathrm{A})$ & + & $\begin{array}{l}\text { Ganciclovir } \\
\text { (from-50 to-10) }\end{array}$ & $\begin{array}{l}\text { Toxoplasmosis } \\
\text { (clinical) }\end{array}$ & NA \\
\hline 6 & $\begin{array}{l}\mathrm{a} \\
\mathrm{b}\end{array}$ & $\begin{array}{l}(-98) \\
0\end{array}$ & $\begin{array}{l}- \\
+(\mathrm{B})\end{array}$ & $\begin{array}{l}- \\
-\end{array}$ & $\begin{array}{l}\text { NA } \\
\text { NA }\end{array}$ & $\begin{array}{l}\text { NA } \\
\text { NA }\end{array}$ & None & $\begin{array}{l}\text { Toxoplasmosis (clinical+necropsy) } \\
\text { PML (necropsy) }\end{array}$ & - \\
\hline 7 & $\mathrm{a}$ & $\begin{array}{l}0 \\
(+100)\end{array}$ & $\begin{array}{l}+(\mathrm{ND}) \\
-\end{array}$ & $\begin{array}{l}+ \\
+\end{array}$ & $\begin{array}{l}- \\
-\end{array}$ & $\begin{array}{l}+ \\
+\end{array}$ & $\begin{array}{l}\text { Ganciclovir } \\
(\text { from }-180 \text { to }+80)\end{array}$ & $\begin{array}{l}\text { CMV encephalitis } \\
\text { (clinical) }\end{array}$ & NA \\
\hline 8 & a† & 0 & $+(\mathrm{ND})$ & + & - & + & None & $\begin{array}{l}\text { Primary lymphoma (biopsy) } \\
\text { CMV encephalitis (clinical) }\end{array}$ & - \\
\hline
\end{tabular}

$\mathrm{NA}=$ sample not available; $\mathrm{ND}=\mathrm{HHV}-6$ variant not defined; +=positive, $-=$ negative.

${ }^{\star}$ In parentheses: number of days before $(-)$ or after $(+)$ CSF sampling in concomitance to onset of neurological disease (0).

†Varicella zoster virus (patient 4) or Epstein-Barr virus (patient 8) was also found in the CSF.

$\ddagger \mathrm{CMV}$ was demonstrated in the same periventricular areas that were found to be HHV6 positive by PCR

\HHV-6 DNA was found in 5 of 13 sections, including cerebral cortex, basal ganglia, and periventricular areas; no additional material was available for examination by the subtype PCR. 
described. ${ }^{11}$ Brain tissue samples from the patients whose CSF was HHV-6-DNA positive were also examined by HHV-6 PCR. ${ }^{11}$

\section{Results}

HHV-6-DNA was found in the CSF of eight of the 365 patients $(2.2 \%$, table). HHV- 6 A was found in two patients and HHV-6 B in four; in the remaining two patients the HHV- 6 variant was not defined, because the subtype PCR yielded a negative result. Multiple CSF specimens were available from six patients: HHV-6 was found in all of the specimens from four of these patients, showing the same viral variant in each patient. CMV-DNA was found concomitantly with HHV-6-DNA in the CSF from five patients (table 1). None of the CSF samples from the $20 \mathrm{HIV}$ seronegative controls was HHV-6-DNA positive.

HHV-6-DNA was found in the plasma of five of seven patients examined. In all cases, the same viral variant was found in CSF and plasma. CMV-DNA was found in plasma from all of the patients whose CSF was HHV-6DNA positive (table). HHV-6-DNA was not found in plasma samples drawn from $22 \mathrm{HIV}$ infected patients with neurological disease whose CSF was HHV-6-DNA negative.

Discordant HHV-6 PCR results between CSF and plasma were seen on six occasions: in all cases, the virus was only found in the CSF. Analysis of the CSF and plasma samples drawn after ganciclovir treatment disclosed persistence of HHV-6 in the CSF but not in the plasma (table).

All of the eight patients had a CD4+ cell count of less than $50 / \mu 1$. In all of these patients clinical neurological findings that could almost always be explained by the presence of other opportunistic CNS diseases were present. Histology confirmed that none of the four patients examined had any identifiable lesions that were not attributable to opportunistic pathogens (table). However, one patient (patient 3) had mild neurological symptoms, consisting of hyposthenia and paresthaesia of the limbs, both before and after the resolution of toxoplasmosis, but in the presence of a HHV-6-DNA positive CSF. In another patient (patient 4), a hemisyndrome with cranial nerve deficits was still present after clearance of both CMV and VZV, but not HHV-6-DNA, from the CSF after ganciclovir therapy.

\section{Discussion}

The aim of this study was to assess the frequency of HHV-6-DNA detection in the CSF of patients infected with HIV, and its possible relation with neurological disease. HHV6-DNA was found in $2.2 \%$ of 365 patients with neurological disease, a detection rate that is similar to that previously found by us for HSV-1, HSV-2, and VZV $(1.6 \%, 0.6 \%$, and $2.6 \%$, respectively), ${ }^{14}{ }^{15}$ but substantially lower than that found for CMV, EBV, and JCV (16\%, $12 \%$, and $9 \%$, respectively). ${ }^{11}$ In a previous report by Liedke et al ${ }^{12}$ HHV-6 was found in the CSF of $30 \%$ of HIV infected patients with neurological problems. However, unlike in our study, HHV-6 was also found in a similar pro- portion of controls, suggesting that different detection rates may depend on the different sensitivity limits of the PCR assays, and that passenger HHV-6 positive blood lymphocytes may be detected in CSF if a very sensitive assay is used. Differently from children with primary infection and patients with multiple sclerosis, in whom the variant B of HHV-6 is predominantly identified, ${ }^{18}$ both variants were found in our patient group. However, and in line with our study, variant $\mathrm{A}$ has also been found in patients with HHV-6 encephalitis, ${ }^{1}$ as well as in children in whom HHV-6 persisted in the CSF after primary infection. ${ }^{16}$

In most patients infected with HIV, the presence of viral genomes in the CSF is associated with clinically significant brain infection. However, we were unable to find a clear association between HHV-6-DNA detection in the CSF and virus induced neurological disease. Opportunistic diseases caused by pathogens other than HHV-6 that could totally explain the neurological symptoms were actually identified in all of our patients whose CSF was HHV-6-DNA positive. Two patients had neurological symptoms before or after the development of opportunistic infections, and in the absence of infectious agents identified other than HHV-6; however, the possibility that symptoms were initial manifestations or sequelae of underlying opportunistic infections cannot be excluded. In neuropathological studies, HHV-6 antigens have been identified in demented patients in the absence of other pathogens, thus suggesting that the virus may play a part in inducing brain disease. ${ }^{11}$ By PCR, we found HHV-6-DNA in the brain tissue of only one of our patients. Although this low detection rate might have resulted from a low sensitivity of PCR on paraffin embedded tissues, again, no relation with unidentified tissue lesions was found in the HHV-6 positive patient.

On the other hand, the fact that HHV-6 was found in almost all of the serial CSF samples taken from our patients, and that both of our PCR assays were positive in six out of eight patients suggests that, at least in these patients, the finding was not incidental. HHV-6 was often detected in plasma of our patients, suggesting that the virus may have spread to the CSF from the blood. However, the frequent discrepancies between the CSF and plasma HHV-6 findings support the hypothesis of an active brain infection by HHV-6, rather than of a passive spread through the blood-brain barrier. We therefore hypothesise that HHV-6 may be found in the CSF after reactivation in the brain or blood, without its presence necessarily inducing neuropathological changes, or clinical disease, or both.

Although no correlation between HHV-6 and HIV infections of the brain could be shown in our study, HHV-6 was found concomitant with CMV in the CSF, plasma, or both in most of our patients. This finding is in agreement with recent reports of tissue HHV-6 and CMV coinfection in organ transplant recipients, ${ }^{17}{ }^{18}$ and of their in vitro interactions, ${ }^{19}$ all support- 
ing a close interrelation between these two herpesviruses.

In conclusion, it is unlikely that HHV-6 plays a prominent part in inducing neurological disease in patients infected with HIV. However, in a small fraction of patients, the virus may reactivate in the brain, and this often occurs concomitant with active CMV brain infection.

This work was supported by a grant from the Istituto Superiore di Sanità, Italy (grant No 50A-006).

1 Braun DK, Dominguez G, Pellet PE. Human herpesvirus 6 [review]. Clin Microbiol Rev 1997;10:521-67.

2 Kondo K, Nagafiji H, Hata A, et al. Association of human herpesvirus 6 infection of the central nervous system with recurrence of febrile convulsions. F Infect Dis 1993;167: $1197-200$.

3 Suga S, Yoshikawa T, Asano Y, et al. Clinical and virological analyses of 21 infants with exanthem subitum (roseola infantum) and central nervous system complications. An Neurol 1993;33:597-603.

4 Caserta MT, Hall CB, Schnabel K, et al. Neuroinvasion and persistence of human herpesvirus 6 in children. $\mathcal{F}$ Infect Dis persistence of hum

5 Drobyski W, Knox KK, Majewski D, et al. Brief report: fatal encephalitis due to variant $\mathrm{B}$ human herpesvirus-6
infection in a bone marrow-transplant recipient. $N$ Engl $\mathcal{F}$ infection in a bone mart $1994 ; 330: 1356-60$.

6 Wang F-Z, Linde A, Hägglund $\mathrm{H}$, et al. Human herpesvirus-6 DNA in cerebrospinal fluid from allogeneic bone marrow transplant patients: does it have a clinical significance? Clin Infect Dis 1999;28:562-8.

7 Kimberlin DW, Whitley RJ. Human herpesvirus-6: neurological implications of a newly described herpesvirus [review]. F Neurovirol 1998;4:474-85.

8 Challoner PB, Kirsten TS, Parker JD, et al. Plaqueassociated expression of human herpesvirus 6 in multiple sclerosis. Proc Natl Acad Sci USA 1995;92:7440-4.

9 Saito Y, Sharer LR, Dewhurst S, et al. Cellular localization of human herpesvirus- 6 in the brain of children with AIDS encephalopathy. $₹$ Neurovirol 1995;1:30-9.
10 Knox KK, Carrigan DR. Active human herpesvirus infection of the central nervous system in patients with AIDS. F Acquir Immune Defic Syndr Hum Retrovirol 1995;9: 69-73.

11 Cinque P, Vago L, Dahl H, et al. Polymerase chain reaction on cerebrospinal fluid for diagnosis of virus-associated opportunistic diseases of the central nervous system in HIV-infected patients. AIDS 1996;10:951-8.

12 Liedtke W, Malessa R, Faustmann PM, et al. Human herpesvirus- 6 polymerase chain reaction findings in human immunodeficiency virus associated neurological disease and multiple sclerosis. $\mathcal{F}$ Neurovirol 1995;1:253-8.

13 Yalcin S, Karpazoglu T, Suleymanlar G, et al. Human herpesvirus 6 and human herpesvirus 7 infections in renal transplant recipients and healthy adults in Turkey. Arch Virol 1994;136:183-90.

14 Cinque P, Vago L, Marenzi R, et al. Herpes simplex viruses infections of the nervous system in human immunodeficiency virus-infected patients: clinical management by polymerase chain reaction analysis of cerebrospinal fluid. Clin Infect Dis 1998;27:303-9.

15 Cinque $\mathrm{P}$, Bossolasco S, Vago L, et al. Varicella-zoster virus (VZV) DNA in cerebrospinal fluid of patients infected with human immunodeficiency virus: VZV disease of the central nervous system or subclinical reactivation of VZV infection? Clin Infect Dis 1997;25:634-9.

16 Hall CB, Caserta MT, Schnabel KC, et al. Persistence of human herpesvirus 6 according to site and variant: possible reater neurotropism of variant A. Clin Infect Dis 1998;26: $132-7$.

17 Herbein G, Strasswimmer J, Altieri M, et al. Longitudinal study of human herpesvirus 6 infection in organ transplant recipients. Clin Infect Dis 1996;22:171-3.

18 DesJardin JA, Gibbons L, Cho E, et al. Human herpesvirus 6 reactivation is associated with cytomegalovirus infection and syndromes in kidney transplant recipients at risk for

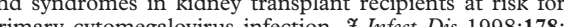
1783-6.

19 Anderson RA, Liu DX, Gompels UA. Definition of a human herpesvirus $6 \beta$ herpesvirus-specific domain in glycoprotein $\mathrm{gH}$ that governs interaction with glycoprotein gL: substitution of human cytomegalovirus glycoproteins permits group-specific complex formation. Virology 1996; 217:517-26. 